SIR,

\title{
Quaternary glaciations in Victoria Land
}

I agree wholeheartedly with the criticism by McGregor ( 1963 ) of the four stages of Quaternary glaciation in southern Victoria Land described by Bull and others (1962).

Figure $\mathrm{I}$ is a photograph taken some weeks ago of the so-called terminal moraines of the "fourth glaciation" in the South Fork of Wright Valley. It is a different view of the same feature illustrated by Bull and others $(1962$, p. 75). As can be seen, this is no terminal moraine but the snout of an almost stagnant glacier, covered by a thin veneer, one or two metres thick, of ablation moraine. The gypsumand halite-encrusted salina pond lies in a depression between the glacier front and old terminal moraines lying between $\mathrm{I}$ and $5 \mathrm{~km}$. down-valley (eastwards), the so-called "third glaciation" moraines. The ice extends beneath moraine for about $4 \mathrm{~km}$. to the west though it appears to be in two parts separated by a second salina pond about $2 \mathrm{~km}$. west. Several kilometres of bare rock separate the western end of this stagnant ice from the present front of the Wright Glacier. Probably the retreat of the glacier front from the "third glaciation" moraines to the position shown in Figure I has taken place since the severing of connection with the Upper Wright Glacier. The boulders littering the floor of the valley are in part ablation moraine and in part rock falls from the valley sides.

As pointed out by McGregor, the coincidence between the postulated "first glaciation" benches and the top of the Peneplain Sill of Ferrar Dolerite (which has been measured as about $350 \mathrm{~m}$. thick in this locality and not roo m. as described by Bull and others), and between the "second glaciation" benches and the Kukri Peneplain (Gunn and Warren, 1962), throws doubt on the existence of any such stages. The moraines of the "third glaciation" do, however, demonstrate an undoubted period of ice advance or, at least, stillstand.

Because of the control exerted by the threshold bars on the amount of ice flowing from the Antarctic Ice Sheet into the outlet glaciers, coupled with the evidence of recent uplift of the Victoria Mountains

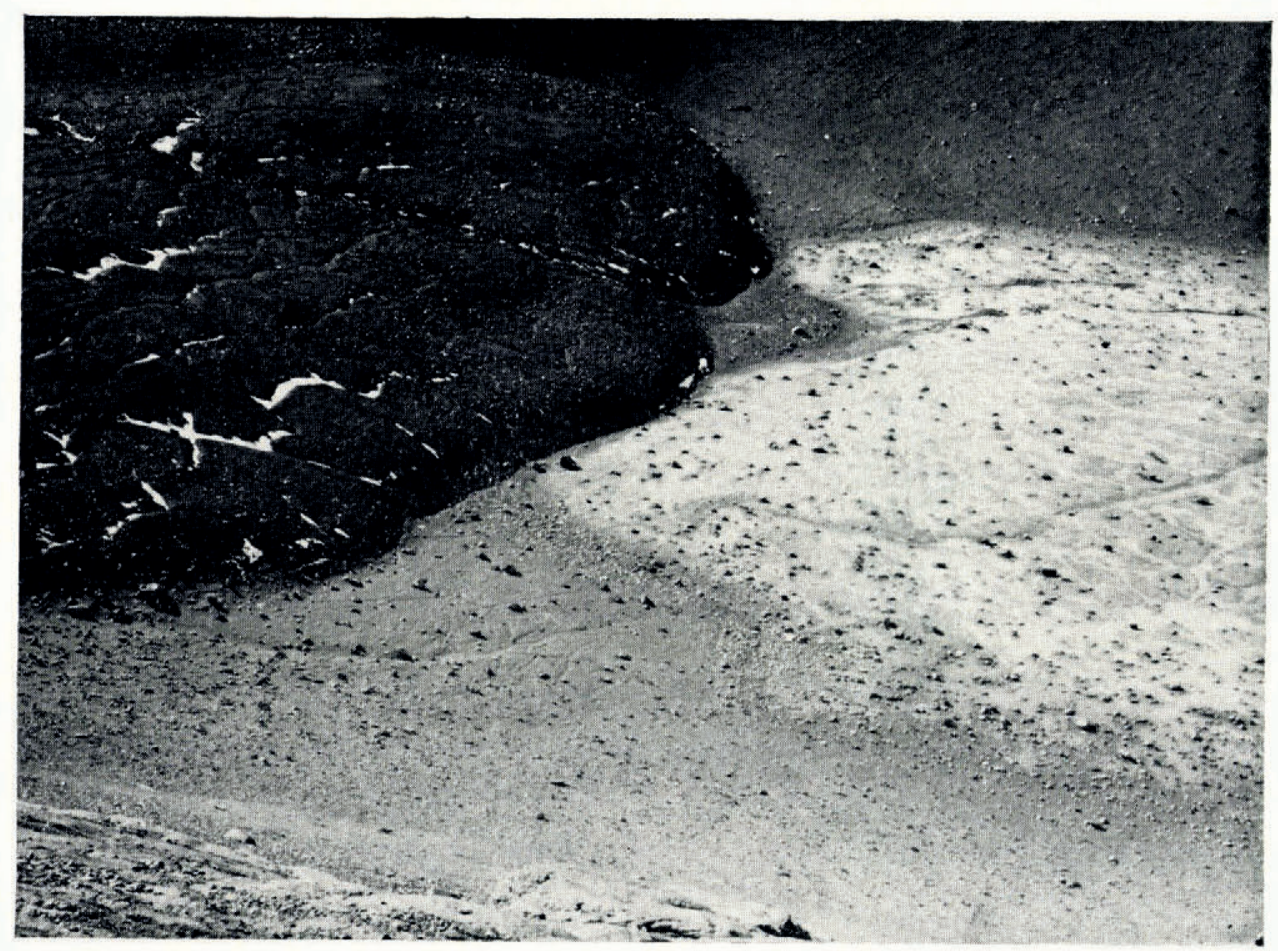

Fig. I. The rock-bound snout of the glacier occupying the South Fork of Wright Valley, southern Victoria Land, with a salina pond occupying the depression between the glacier ice and old terminal moraines down-valley (eastwards). West is to the left of the photograph and east to the right 
suggested by the presence of raised beaches along the coast, I consider that only the alpine glacier valleys can be used to study glacial periods.

Glacial erratics litter the mountainsides in southern Victoria Land and are scarcer at higher altitudes probably due to local glacier action, but I have not observed any clearly defined upper limit.

The glacial periods of Péwé (1960) are more firmly based on moraines than on benches, but fundamental misconceptions of the topography of the then only partly mapped area render his "Koettlitz Glaciation" to have a very doubtful existence.

Department of Geology,

Bernard M. GunN

University of Otago,

Dunedin,

New Zealand

28 March 1963

\section{REFERENCES}

Bull, C., and others. 1962. Quaternary glaciations in southern Victoria Land, Antarctica, by C. Bull, B. C. McKelvey and P. N. Webb. Journal of Glaciology, Vol. 4, No. 31, p. 63-78.

Gunn, B. M., and Warren, G. 1962. Geology of Victoria Land between the Mawson and Mulock Glaciers, Antarctica. Geological Survey of New Zealand. Bulletin 7r.

McGregor, V. R. 1963 . Structural or glacial benches? Fournal of Glaciology, Vol. 4, No. 34, p. 494-95. [Letter.] Péwé, T. L. I960. Multiple glaciation in the McMurdo Sound, Antarctica-a progress report. Ohio State University Research Foundation. Report $825^{-2}$-Part IX, p. 1-27. 